\title{
Efeito do tratamento com implante intravaginal de progesterona sobre a contagem de folículos antrais em éguas na fase de transição do anestro para a estação reprodutiva
}

Hiago Cortezini Hadid ${ }^{[a]}$, Gustavo Romero Gonçalves ${ }^{[a]}$,Fabio Luiz Bim Cavalieri[b],Antonio Hugo Bezerra Colombo ${ }^{[b]}$,Fábio Morotti ${ }^{[a]}$, Marcelo Marcondes Seneda ${ }^{\left.[]^{[}\right]}$

\footnotetext{
[a] Universidade Estadual de Londrina (UEL), Londrina, PR, Brasil

${ }^{[b]}$ Gestar Embriões - Reprodução Animal, Maringá, PR, Brasil
}

*Autor correspondente

e-mail: hiago_hadid@hotmail.com

\section{Resumo}

A contagem de folículos antrais (CFA) é um parâmetro que vem sendo estudado nos últimos anos como potencial marcador biológico para a eficiência reprodutiva nos animais. Em bovinos, há consenso de que a CFA mais alta tem relação direta com a fertilidade. Na espécie equina são escassas as informações sobre o tema. Este trabalho teve como objetivo investigar os efeitos do tratamento com implante de progesterona (P4) sobre a contagem de folículos antrais em éguas na fase de transição do anestro para o estro. Para isso, foram utilizadas éguas $(n=21)$ sem raça definida, de propriedades da região da cidade de Londrina, separadas em Grupo Controle ( $n=11$ ), sem tratamento com progesterona, e Grupo P4 ( $n=10$ ), no qual foi usado implantes de progesterona. Essas éguas foram avaliadas através de ultrassonografia transretal, por um único operador experiente, em dias intercalados, para a contagem dos folículos antrais até o momento da ovulação ou atresia do folículo dominante. Os dados foram analisados quanto à normalidade de distribuição pelo teste de Anderson-Darling e quanto à homogeneidade de variâncias pelo teste de Levene. Após avaliação de D0 até D24, constatou-se que as éguas que receberam implante de P4 apresentaram maior contagem de folículos antrais $(9,6 \pm 3,4)$ quando em comparação aos animais do grupo controle $(8,5 \pm 2,3 ; \mathrm{P}<0,05)$. Verificou-se ainda uma constância no número de folículos em cada indivíduo, sem variação significativa ao longo do período estudado $(\mathrm{P}=0,28)$. Concluímos que o tratamento com implantes intravaginais de progesterona em éguas na transição do anestro para o estro apresentou relação com maior contagem de folículos antrais.

Palavras-chave: Contagem de folículos antrais. Implante intravaginal. Progesterona. 